\title{
Women, the Recited Qur'an, and Islamic Music in Indonesia, by Anne K. Rasmussen
}

Berkeley: University of California Press, 2010 | xx + 31 2 pages | ISBN: 978-0-520-25548-7 (hardback) \$65.00 | ISBN: 978-0-520-25549-4 (softback) \$29.95

This book considers a component-the teaching, learning and reciting of the Qur'ān—of $a$ religion-Islam — in a country-Indonesia-in great de-

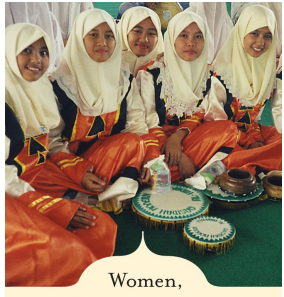

the Recited Qur'an, and Islamic Music in Indonesia

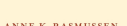
tail, depth and with great distinction. Rasmussen considers, and demonstrates with a comparison to opera (25), the recitation together with related aspects - teaching and learning thereof-to be a humanly-generated musical art. The main contribution of Rasmussen's text is no doubt in relation to musicology, and its value in determining what the author terms "soundscapes," that is, sound as information and hearing as knowing (2 I 2). For the author, understanding soundscapes adds an important and vital dimension to our appreciation of the way in which humans mediate religious symbols.

The book could not focus on musicology related to the recitation of the Qur'ann without touching, significantly, on the study of religion in contemporary society. Accordingly, the book highlights many of the dimensions and fissures addressed by the study of religion. The main aspects here are the nature, construction and reconstruction of authority over foundational texts. The question of how authority over foundational texts intersects with past and existing geopolitical power structures, ethnicity and gender becomes a central aspect of Rasmussen's work.

Those interested in women, Islam, music and Indonesia will find the book invaluable as well as interesting. Those partial to one or a combination of the issues on which she concentrates would also not be sorry to pick the book up. While the book focuses, specifically, on how Muslim women in Indonesia contribute - through teaching, learning and reciting - to the presence of the oral Qur'ann in Indonesian society, the book also comments on features of Indonesia's politics and economics. In other words the book's scope far outweighs its specific focus.

Rasmussen's book forms part of an overwhelming body of literature on forms of Islam which are central to contemporary geopolitics. Rasmussen's study is however not intended, directly, to lead this debate in a particular direction. What she does, because of a long-standing relationship to her research site and rigorous ethnographic research, is add richness and complexity 
to debates surrounding the place of Islam and Islamic cultures in contemporary social research. She comments, notably, on notions of global and local, traditional and modern, and how these issues emerge, not without tension, in her study of religion and music with respect to women in Indonesia. For example Rasmussen argues that traditional modes of Islamic practice in Indonesia present women with greater opportunity to engage religious symbols and activities in public than do modern modes.

As with any text about women and Islam, the book must comment on the place of Muslim women in relation to power. Rasmussen notes the distinction made between feminism and "Islamic womanism," the latter determined to reconstruct foundational texts without the overlay of patriarchal power structures. In other words, womanists are determined that Islam is for women as much as it is for men, and that there is no reason to change it. One merely has to locate where men have interpreted foundational texts to their advantage. Rasmussen suggests that womanists have already unearthed sufficient evidence to illustrate that this is possible. Furthermore, she postulates that the main protagonist in her study, a female reciter of the Qur'ān, embodies a non-patriarchal reading of the Qur'ann.

Less engagingly but importantly, the book points out the lack, despite recent exceptions, of attention to Indonesian Islam as a vernacular of the practices of this religion in favour of Middle Eastern Islam. For example, Islam spread to South Africa via Indonesia and Dutch colonisation of the region and not from the Arabian Peninsula. The text, refreshingly, does not proceed to admonish and present caveats related to Islam and things Islamic or the practices of Muslims. Rather the text demonstrates what passionate, meticulous and serious research can mean for understanding society-anywhere-in meaningful ways. Rasmussen demonstrates perfectly her expertise in this field, no doubt gained from serious study over an extended period.

If forced to critique this text it would have to be on the level of technical aspects with respect to music for those coming to the book from other fields. In the same breath, however, one does not need to "get it" - that is, the technical aspects of music - to fully grasp the argument Rasmussen makes or the importance her work has for coming to grips with the Qur'ān as the primary foundational text of Islam. 